\title{
The Effect of the Aerobic Training on Morphological and Histochemical Characteristics of Tibial Anterior Muscle in Rats Fed with High Fat Diet
}

\author{
Efecto de un Programa de Entrenamiento Aeróbico sobre las Características Histológicas y \\ Morfológicas del Músculo Tibial Anterior de Ratas Alimentadascon Dietas Elevadas en Grasa \\ "Ciabattari, O.; **Dâmaso, A. R.; ***Dal Pai, V.; ${ }^{* * * *}$ Dal-Pai-Silva, M. \& ${ }^{* * * * *}$ Freitas Jr, I. F.
}

CIABATTARI, O.; DÂMASO, A. R.; DAL PAI, V.; DAL-PAI-SILVA, M. \& FREITAS JR, I. F. The effect of the aerobic training on morphological and histochemical characteristics of tibial anterior muscle in rats fed with high fat diet. Int. J. Morphol.,26(4):1053$1058,2008$.

SUMMARY: The aim of this study was to investigate the effect of high fat diet and different frequencies of swimming programs in the tibial anterior muscle in male Wistar rats. In conclussion, the aerobic training during two days/week and five days/week caused injuries in muscle fibers and the high fat diet did not cause statically significant results compared to normal diet.

KEY WORDS: Aerobic training; Morphology; Skeletal muscle; Rats; Fat diet.

\section{INTRODUCTION}

Obesity, considered a worldwide disease in 1997 by the World Health Organization (Ross et al., 2000), has risen enormously over the past few decades and has reached epidemic proportions in both developed and developing countries, affecting not only adults but also children and adolescents. In some parts of North America, Canada, Eastern Europe, Middle East, Pacific Islands, Australia and China obesity rates have increased 3-fold, since 1980 (Stieger \& Cunliffe, 2006). In Brazil, obesity reaches $45 \%$ of the population (Guerra et al., 2002). Although the sedentary lifestyle had supplanted physical labor and regular physical activity, some researchers suggest that, in recent decades, changes in diet habits had a dramatic effect on this increasing and alarming worldwide epidemy. In the USA, the intake of chips/crackers/popcorn/pretzels roughly tripled from the mid-1970s to the mid-1990s (Sturm, 2005).

People who are overweight or obese have substantially increased risk for morbidity and mortality from numerous chronic disorders, such as diabetes, hypertension and cardiovascular disease, dislipidemia, gallbladder disease, sleep apnea, infertility, osteoarthritis and some forms of cancer (Ross et al.; Stiegler \& Cunliffe; Pollock et al., 1998; Anderson \& Wadden, 2000; Stevens et al., 2002; Pedersen, 2007). In recent years, some research has shown that one of the most effective methods which can lead to obesity control is physical activity.

The aim of this study was to investigate the effect of different frequencies of swimming exercise in rats fed with high fat diet on morphology and histochemical characteristics in tibial anterior skeletal muscle.

\section{MATERIAL AND METHOD}

Twenty four male Wistar rats (Rattus norvegicus albinus), aged 90 days, from Central Biotério of Sao Paulo State University (UNESP), Campus of Botucatu, were used in this study. The animals were maintained in the Bioterio of UNESP, Campus of Presidente Prudente, place where the experiment was made, housed four per cage in a temperaturecontrolled room $\left(24^{\circ} \mathrm{C}\right)$ and a 12-h light/dark cycle. The

\footnotetext{
* Department of Exercise Physiology, Federal University of São Paulo - UNIFESP-EPM, São Paulo, Brazil.

** Department of Biosciences - Federal University of São Paulo - Paulista Medicine School.- UNIFESP, São Paulo, SP, Brazil.

*** Department of Histology, University of Western São Paulo-UNOESTE, Presidente Prudente, São Paulo, Brazil.

***** Department of Morphology, Bioscience Institute São Paulo State University-UNESP, Campus Botucatu, São Paulo, Brazil.

****** Department of Physical Education, São Paulo State University-UNESP, Campus of Presidente Prudente, São Paulo, Brazil.
} 
rats were fed with one of two diets as follows: One group $(\mathrm{n}=12)$ received standard chow produced by Nuvital Nutrients Ltda (NUVILAB-CR1) (Colombo, PR, Brazil)Ò, The other group $(n=12)$, received a high fat diet (cafeteria diet) (Rotchell \& Stock, 1981; Prats et al., 1989) formulated by Nutrition and Metabolism Laboratory of Federal University of Sao Carlos (DEFMH/CCBS/UFSCAR). Food and water were available ad libitum.

The rats were assigned in six sub-groups (4 animals each) and remained sedentary, until their weight reached at least $350 \mathrm{~g}$ After the period the groups were distributed as follows:Two control sub-groups remained sedentary, one ingested standard chow pellet (SS), and the other ingested a high fat diet (SH) throughout the experimental period;

Four sub-groups were exercised: two groups, two times per week in an intermittent way, and two groups were exercised five times per week on continuous way. One of each group ingested a standard chow pellet (CS) and the other ingested a high fat diet $(\mathrm{CH})$. The sequence of intermittent group and continuous group had been based on Duarte's protocol (Duarte, 2001). The training consisted of continuous swimming for $60 \mathrm{~min} /$ day, on consecutive days, during 10 weeks. This exercise was performed in tanks of water with the capacity for 10 animals, measuring $40 \times 60 \times 80 \mathrm{~cm}$. The water temperature was maintained between $32^{\circ} \mathrm{C}$ and $36^{\circ} \mathrm{C}$ and was changed daily.

The surgical procedure began twenty-four hours after the last training, with intraperitoneal anaesthesia of sodium Thiopental (20mg/100g corporal weight). After this the animals were weighed in the electronic scale $(\mathrm{g})$ and the tibial anterior muscle was removed and stained with Hematoxylin and Eosin (HE) and Sudan Black (Dubowitz, 1985). The morphology was analyzed and the degree of fiber growth evaluated using the lesser fiber diameter method (Dubowitz). This procedure allowed the identification of three different types of staple fibres: Fast-twitch-glycolytic (FG); Fasttwitch-oxidative-glycolytic (FOG) and Slow-twitchoxidative (SO). The results are expressed as means \pm standard deviation. The comparisons of the absolute data among groups were performed by ANOVA, followed by Least Significant Difference post-hoc test for multiple comparisons. The level of significance was set at $\mathrm{P}<0.05$. All analysis was performed using the SPSS software, version 13.0 (SPSS Inc, Chicago, IL).The ethical committee of Universidade do Oeste Paulista approved all procedures of this research.

\section{RESULTS}

The comparison of body weight of the rats in the beginning and ending of the study are presented in the Table I. In the Table II are presented the amount and percentage of fibers according to their diameters. The three groups high fat fed presented higher proportion of hypertrophic fibers. Table III is indicated fiber's hypertrophy in groups. The IN, IH and IS showed hypertrophy statistically significant.

In the Fig. 1 fibers are stained with Hematoxylin and Eosin (HE). The SS and SH groups showed fibers with different diameter, polygonal shape, myonuclei $(\mathrm{M})$ and some hypertrophic fibers $(\mathrm{H})$, this last is also observed in some cells of IS group. The $\mathrm{CS}$ and $\mathrm{CH}$ muscle samples showed more damaged cells, with basophilic (B), some round cells, atrophic cells and splitting (longitudinal segmentation of the cytoplasm) with internal nuclei. In the IH group there were also observed atrophic fibers and splitting.

In the Fig. 2 the transversal section of tibial anterior muscle are stained with Sudan Black. The SS and SH groups, present SO fibers with a high lipids concentration, more evident in the subsarcollemal region; FOG fibers with

Table I. Mean and standard deviation of body weight ( $\mathrm{g}$ ) of the rats and comparisons among different groups, and comparisons of the initial and final weight of each group.

\begin{tabular}{clll}
\hline Groups & Initial weight & Final weight & P value \\
\hline SS & $450.0 \pm 58.63$ & $489.4 \pm 52.16$ & 0.05 \\
SH & $435.0 \pm 37.91^{\mathrm{b}}$ & $523.5 \pm 52.36^{\mathrm{abc}}$ & 0.03 \\
IS & $425.0 \pm 30.62^{\mathrm{b}}$ & $518.1 \pm 14.78^{\mathrm{abc}}$ & 0.002 \\
IH & $443.8 \pm 37.50^{\mathrm{ab}}$ & $551.0 \pm 50.74^{\mathrm{c}}$ & 0.005 \\
CS & $368.8 \pm 12.50^{\mathrm{ab}}$ & $469.6 \pm 14.06^{\mathrm{ab}}$ & 0.001 \\
CH & $430.0 \pm 41.08^{\mathrm{b}}$ & $545.1 \pm 37.32^{\mathrm{c}}$ & 0.005 \\
\hline
\end{tabular}

$\mathrm{SS}=$ Sedentary normal diet fed; SH= Sedentary hypercaloric diet fed; IS = Intermittent trained normal diet fed; $\mathrm{IH}=$ Intermittent trained hypercaloric diet fed; $\mathrm{CS}=$ Continuous trained normal diet fed; $\mathrm{CH}=$ Continuous trained and hypercaloric fed; Superscript letters means statistical differences among groups in the beginning and in the final of experiment. 
CIABATTARI, O.; DÂMASO, A. R.; DAL PAI, V.; DAL-PAI-SILVA, M. \& FREITAS JR, I. F. The effect of the aerobic training on morphological and histochemical characteristics of tibial anterior muscle in rats fed with high fat diet. Int. J. Morphol.,26(4):1053-1058, 2008.

Table II. Distribution of fibers of tibial anterior muscle, according to their diameters.

\begin{tabular}{lccccc}
\hline Groups & \multicolumn{5}{c}{ Fibers diameters $(\boldsymbol{\mu m})$} \\
\cline { 2 - 6 } & $\mathbf{N}$ & $<20$ & $21-40$ & $41-60$ & $>60$ \\
\hline SS & 400 & $174(40.7 \%)$ & $214(50.1 \%)$ & $39(9.1 \%)$ & \\
SH & 400 & $3(0.7 \%)$ & $146(35.7 \%)$ & $204(49.8 \%)$ & $57(13.9 \%)$ \\
IS & 400 & $151(37.5 \%)$ & $150(37.5 \%)$ & $99(24.7 \%)$ & \\
IH & 400 & $1(0.2 \%)$ & $139(34.7 \%)$ & $217(54.2 \%)$ & $43(10.7 \%)$ \\
IS & 400 & $118(29.5 \%)$ & $221(55.2 \%)$ & $60(15.0 \%)$ & \\
CH & 400 & $1(0.2 \%)$ & $116(29.0 \%)$ & $189(47.2 \%)$ & $95(23.7 \%)$ \\
\hline
\end{tabular}

$\mathrm{SS}=$ Sedentary normal diet fed; $\mathrm{SH}=$ Sedentary hypercaloric diet fed; $\mathrm{IS}=$ Intermittent trained normal diet fed; $\mathrm{IH}=$ Intermittent trained hypercaloric diet fed; $\mathrm{CS}=$ Continuous trained normal diet fed; $\mathrm{CH}=$ Continuous trained and hypercaloric fed

Table III - Comparison of fiber size $(\mu \mathrm{m})$ of the different experimental groups.

\begin{tabular}{cccccc}
\hline & & & & \multicolumn{2}{c}{ Confidence interval 95\% } \\
\cline { 5 - 6 } & N & mean & sd & Lower bound & Upper bound \\
\hline SS & 427 & $45.13^{\mathrm{a}}$ & 10.99 & 44.09 & 46.18 \\
SH & 409 & $45.64^{\mathrm{a}}$ & 12.61 & 44.42 & 46.87 \\
IN & 400 & $49.26^{\mathrm{b}}$ & 16.40 & 47.64 & 50.87 \\
IH & 400 & $46.60^{\mathrm{a}}$ & 11.39 & 45.48 & 47.72 \\
IS & 400 & $46.87^{\mathrm{a}}$ & 13.08 & 45.59 & 48.16 \\
CH & 400 & $50.37^{\mathrm{b}}$ & 14.46 & 48.91 & 51.75 \\
\hline
\end{tabular}

SS = Sedentary normal fed; SH= Sedentary High fat fed; IN= Intermittent normal fed; $\mathrm{IH}=$ Intermittent high fat fed; IS= continuous normal fed; $\mathrm{CH}=$ continuous high fat fed. Different subscript letters, means statistical difference.

moderate lipids concentration and weak lipid concentration in FG fibers. The IN group presents high lipids concentration on SO and FOG fibers and weak reaction in FG fibers. In the IH group, lipids concentration is higher in FG compared to $\mathrm{SO}$ and FOG fibers. The CS group presented greater lipids concentration in SO, FOG and FG fiber, compared to the other groups. In the $\mathrm{CH}$ group, $\mathrm{SO}$ and FOG fibers presented high lipids concentration compared to FG fiber, which showed weak reaction.

\section{DISCUSSION}

The data reported in the present study indicate that the tibial anterior muscle showed different diameter fibers between $45.1 \mu \mathrm{m}$ in SS group to $53.03 \mu \mathrm{m}$ in $\mathrm{CH}$ group and the mosaic pattern of fibers did not present alterations between sedentary and trained groups. The protocol used in this study was in concordance with the position stand of American College of Sports Medicine (Pollock et al.).
Weight training alone without diet had little effect on body fat mass but resulted in a $1 \mathrm{~kg}$ gain in lean body mass in obese young women (Zachwieja, 1996). Dall Pai et al. (1983, 1984) presented in the postnatal growth of rats that fibers is in a very active process, with extend from $12^{\text {th }}$ to the $45^{\text {th }}$ live day. The fibers show a linear enlargement, presenting at the same time the highest rates of growth. Extending from $45^{\text {th }}$ to $180^{\text {th }}$, muscle fibers present a markedly fall in the growth rates, except for white fibers (FG).

The trained groups, especially $\mathrm{CS}$ and $\mathrm{CH}$ showed several morphological alterations: splitting, basophily, hypertrophy and muscle fiber with small diameter, like denervation condition; muscle fibers in phagocytosis process, accentually in both continuous groups (normal and hypercaloric) were observed. The presence of 0.2 to $0.7 \%$ of muscle fibers with diameter less than $20 \mu \mathrm{m}$ between control and trained hypercaloric groups, suggest that the protocol did not showed significant effect on the number of the fibers; the occurrence of muscle fiber with small diameter can be resulted of atrophic process drawn out and/or new fiber formation 

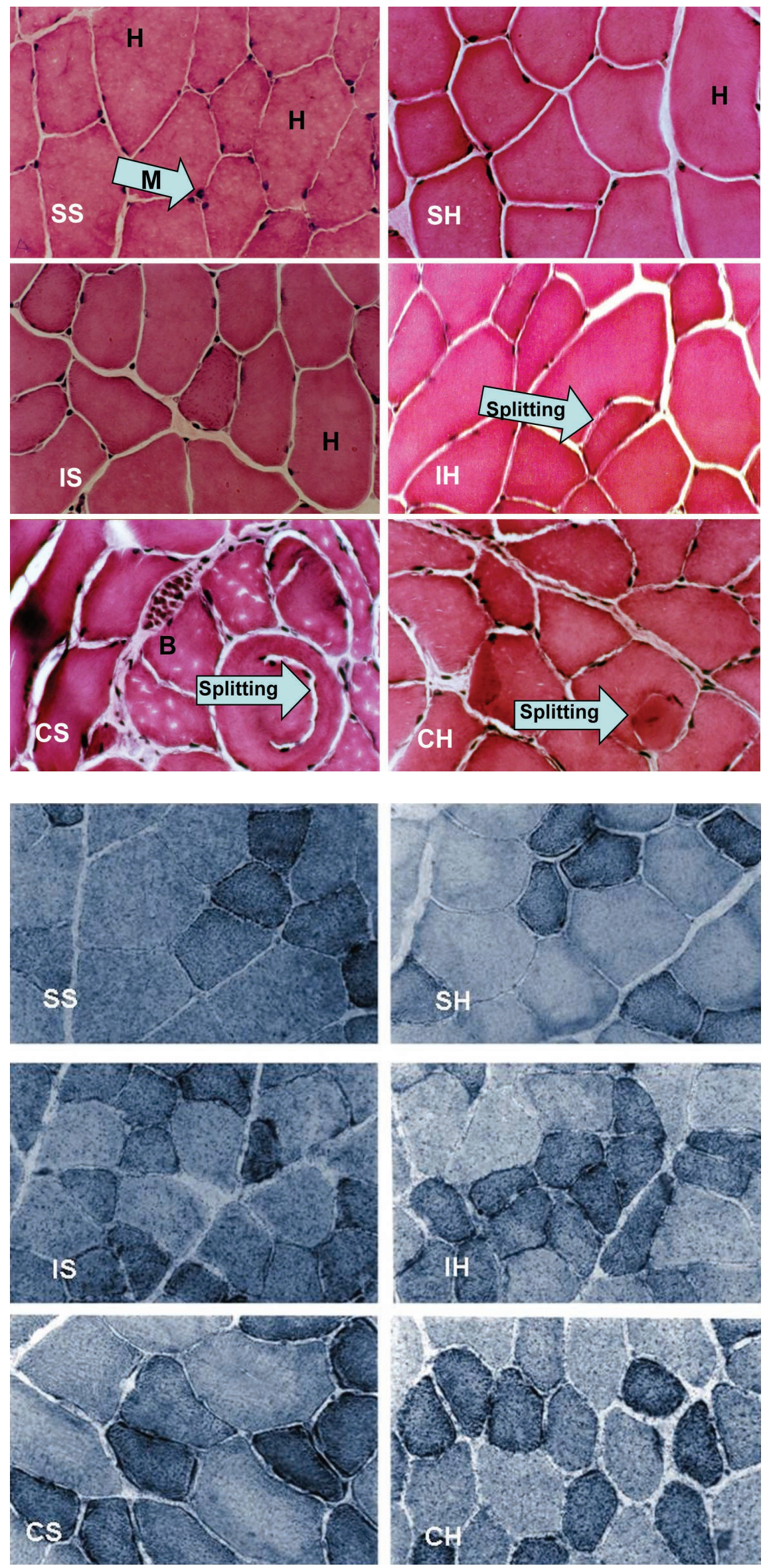

Fig. 1. Cross section of tibial anterior muscle of Wistar rats. $\mathrm{SS}=$ Sedentary normal diet fed; $\mathrm{SH}=$ Sedentary hypercaloric diet fed; IS = Intermittent trained normal diet fed; $\mathrm{IH}=$ Intermittent trained hypercaloric diet fed; $\mathrm{CS}=$ Continuous trained normal diet fed; $\mathrm{CH}=$ Continuous trained and hypercaloric fed. M=Myonuclei; $\mathrm{H}=$ Hypertrophic fibers; $\mathrm{B}=\mathrm{B}$ asophils. Stained with haematoxylin-eosin (original $\mathrm{x} 128)$.

Fig. 2. Transversal section of tibial anterior muscle. $\mathrm{SS}=$ Sedentary normal diet fed; $\mathrm{SH}=$ Sedentary hypercaloric diet fed; IS = Intermittent trained normal diet fed; $\mathrm{IH}=$ Intermittent trained hypercaloric diet fed; $\mathrm{CS}=$ Continuous trained normal diet fed; $\mathrm{CH}=$ Continuous trained and hypercaloric fed. Sudan Black $128 \mathrm{X}$ 
(Mastaglia \& Walton, 1982) .Similar results were seems by Camargo et al. (2003) which showed atrophic and phagocyted fibers, round shape fibers and internal nuclei accentually in rats trained 5 days/week, $60 \mathrm{~min}$, during 60 days.

On the other hand, exercise can be an excellent way to prevention the complications associated with obesity with a preferential loss at fat from abdominal region (Zachwieja). In particularly the fat is an abundant energy reserve. Fat utilization is under coordinated metabolic control and can only occur under aerobic conditions (Stefanick, 1993). Helge et al. (1996) investigated the fat utilization during exercise in male untrained subjects and demonstrated that VLDLTG made a significant contribution to fuel utilization during exercise after adaptation to a fat-rich diet. Lee et al. (2001) studied interaction of different exercises (low and high intensity) and diet (high-fat vs. high-carbohydrate) in rats. The results showed that the regular aerobic training evoked a multitude of biochemical adaptations in skeletal muscle and liver with decreased utilization of carbohydrate and increase in the oxidative lipid in untrained animals fed a high-fat diet.

Further a biochemical adaptation in skeletal muscle, Cameron-Smith et al. (2003) reported a short-term, high-fat diet up-regulates lipid metabolism and gene expression in well-trained male cyclists and triathletes muscle and the result showed that fatty acids, in addition to their important role as energy-yielding nutrients, may exert a significant influence on the regulation of gene expression. The impact of peripheral signals, such as ghrelin and leptin were studied by Christi et al (2006) in the effect of increase lipid intake while maintaining carbohydrate intake constant on hormonal responses during aerobic exercise in endurance-trained men. The results showed that the hormones considered being involved in energy homeostasis (ghrelin, GH, leptin and insulin) respond differently during state of acute negative energy balance with an increase in ghrelin and $\mathrm{GH}$ and a tendency for a decrease in leptin and insulin. It is possibly that the some similar effects can be happened in this present study that demonstrated a significant effect of the diets (normal and high fat) on the initial and post intervention body weight of the trained groups.

Zachwieja, studied exercise as treatment for obesity and related that the mode of activity may affect the success of an exercise intervention and comparing swim training with treadmill exercise at a similar intensity (heart rate equivalent of $75 \%$ of treadmill $\mathrm{VO} 2 \mathrm{max}$ ) produced equal improvements in cardiovascular fitness and body composition. This study points to the possibility that swimming exercise could be included as one of several modes of physical activity available to treat or prevent obesity.

In conclusion the swimming training caused morphological alterations, some of them similar to that observed in muscle denervation conditions. Hypertrophy was statistically significant in IN, IH and IS groups and it might be benefiting in body composition adjustment to improve obesity control in who fed with high fat diet.

CIABATTARI, O.; DÂMASO, A. R.; DAL PAI, V.; DAL-PAI-SILVA, M. \& FREITAS JR, I. F. Efecto de un programa de entrenamiento aeróbico sobre las características histológicas y morfológicas del músculo tibial anterior de ratas alimentadas con dietas elevadas en grasa. Int. J. Morphol.,26(4):1053-1058, 2008.

RESUMEN: El objetivo de este estudio fue investigar el efecto de dietas ricas en grasas y diferentes frecuencias de natación, en el músculo tibial anterior, de ratas machos Wistar. El entrenamiento aeróbico, durante dos y cinco días por semana, causó lesiones en las fibras musculares y la dieta alta en grasa, no produjo resultados estadísticamente significativos, en comparación con la dieta normal.

PALABRAS CLAVE: Entrenamiento aeróbico; Morfología; Dietas ricas en grasas; Tejido muscular.

\section{REFERENCES}

Anderson, D. A. \& Wadden, T. A. Tratando o Paciente Obeso: Sugestões para a Prática de Atendimento Primário. JAMA, 4:3172-87, 2000.

Camargo, R. C. T.; Camargo Filho, J. C. S.; Vanderlei, L. C. M.; Oliveira Júnior, A. S. \& Oliveira, D. A. R. Efeitos do Treinamento Físico através da esteira rolante sobre o músculo sóleo de rato. Anais da XVIII Reunião Anual da FeSBE, Curitiba, 2003.
Cameron-Smith, D.; Burke, L. M.; Angus, D. J.; Tunstall, R. J.; Cox, G. R.; Bonen, A.; Hawley, J. A. \& Hargreaves, M. A short-term, high-fat diet up-regulates lipid metabolism and gene expression in human skeletal muscle. Am. J. Clin. Nutr., 77:313-8, 2003.

Christ, E. R.; Zehnder, M.; Boesh, C.; Trepp, R.; Mullis, P. E.; Diem, P. \& Decombaz, J. The effect of increased liquid intake lipid intake on hormonal responses during 
CIABATTARI, O.; DÂMASO, A. R.; DAL PAI, V.; DAL-PAI-SILVA, M. \& FREITAS JR, I. F. The effect of the aerobic training on morphological and histochemical characteristics of tibial anterior muscle in rats fed with high fat diet. Int. J. Morphol.,26(4):1053-1058, 2008.

aerobic exercise in endurance-trained men. Eur. $J$. Endocrinol., 154:397-403, 2006.

Dall Pai, V.; Macha, N, \& Curi, P. R. On the cross sectional area of skeletal muscle fibres of the rat. Anat. Anz., 154:337-41, 1983.

Dall Pai, V.; Thomaz, E. \& Curi, P. R. Postnatal growth of skeletal muscle fibres of the rat. Gegenbaurs Morph. Jahrb., 130:827-34, 1984.

Duarte O. F. Adaptações metabólicas a dois tipos de treinamento moderado de natação, contínuo e intermitente, em ratos machos adultos alimentados com dieta normocalórica e hipercalórica. Dissertação de Mestrado. UFSCar. São Paulo, 2001.

Dubowitz, V. Muscle biopsy: modern approach. 2. ed. London, Bailliere Tindall, 1985. pp.41-81.

Guerra, R. L. F.; Cunha, C. T. da; Montes, R. S.; Junior, J. A. S.; Dias, A. \& Damaso, A. R. Efeitos do exercicio cronico com orientação nutricional sobre parâmetros lipídicos de mulheres obesas. Rev. Bras de Fisioter., 6:(1):1-7, 2002.

Helge, J. W.; Richter, E. A. \& Kiens, B. Interaction of training and diet on metabolism and endurance during exercise in man. J. Physiol., 492(1):293-306, 1996.

Lee J. S.; Bruse, C. R.; Spriet, L. L. \& Hawley, J. A. Interaction of diet and training on endurance performance in rats. Exp. Physiology, 86(4):499-508, 2001.

Mastaglia, F. L. \& Walton, J. Skeletal Muscle Pathology. In: Landon D.N. Skeletal muscle - normal morphology, development and innervations. Edinburgh, Churchill Livingstone, 1982. pp.1-87; 89-94

Pedersen, B. K. Body mass index-independent effect of fitness and physical activity for all-cause mortality. Scand. J. Med. Sci. Sports, 17:196-204, 2007.

Pollock, M. L.; Gaesser, Glenn, A.; Butcher, J. D.; Despres, J. P.; Dishman, R. K.; Franklin, B. A. \& Garber, C. E. ACSM Position Stand: The Recommended quantity and quality of exercise for maintaining cardiorespiratory and muscular fitness, and flexibility in healthy adults. Med. Sci. Sports Exerc., 30(6):975-91, 1998.

Prats, E.; Monfar, M.; Castellà, J.; Iglesias, R. \& Alemany M. Energy intake of rats fed a cafeteria diet. Physiol. Behav., 45(2):263-72, 1989.
Ross, R.; Dagnone, D.; Jones, P. J. H.; Smith, H.; Paddags, A.; Hudson, R. \& Janssen, I. Reduction in obesity and related comorbid after diet-induced weigh loss or exerciseinduced weight loss in men American. Ann. Intern. Med., 133:92-103, 2000.

Rothwell, N. J. \& Sotck, M. J. A role for insulin in the dietinduced thermogenesis of cafeteria-fed rats. Metabolism, 30:673-8, 1981

Stefanick, M. I. Exercise and weight control. In: Holloszy, J. O., editor. Exerc. Sport. Sci. Rev., 21:363-96, 1993.

Stevens, J.; Cai, J.; Evenson, K. R. \& Thomas, R. Fitness and fatness as predictors of mortality from all causes and from cardiovascular disease in men and women in the lipid research clinics study. Am. J. Epidemiol., 156:832-41, 2002.

Stiegler, P. \& Cunliffe, A. The role of diet and exercise for the maintenance of fat-free mass and resting metbaolic rate during weight loss. Sports Med. 36(3):239-62, 2006.

Sturm, R. Childhood Obesity - What we can learn from existing data on societal trends, Part 2. Prev. Chronic Dis., 2(2):1-9, 2005.

Zachwieja, J. J. Exercise as Treatment for obesity. Endocrinol. Metab. Clin. North. Am., 25(4):965-88, 1996.

Correspondence to:

Ana R. Dâmaso, PhD.

Department of Biosciences

Federal University of Sâo Paulo - Paulista

Medicine School - UNIFESP

Rua Marselhesa, 535

CEP: 04.020-060

São Paulo, SP

BRAZIL

Phone: 55 11-55720177.

E-mail: ana.damaso@unifesp.br

Received: 08-04-2008

Accepted: 25-09-2008 